\title{
Ex
}

\section{Verifying Entitlement to Treaty Benefits}

\author{
J. David B. Oliver, Coopers \& Lybrand, London
}

Much attention has been focused recently on entitlement to treaty benefits and in particular on the so called limitation on benefits article (Article 26) in the US/Netherlands Treaty. The principal treaty benefits which in practice are affected by such provisions are those concerning the taxation of dividends, interest and royalties. Each of these streams of income will usually be subject to withholding tax in the source state.

There are, broadly, two approaches to the granting of treaty benefits in relation to such withholding taxes. One approach is to require withholding of tax at source in all cases. The recipient is then required to make a claim for a refund under the treaty on each occasion. This allows the source state to verify each time the entitlement of the recipient to the refund. If there is doubt about the matter or, more particularly, it is considered that the recipient is not entitled to the refund under the treaty criteria then it will be refused. This leaves the source state in a strong position to enforce the terms of the treaty. Even in cases where treaty relief may be given at source at the direction of the tax authorities this will be as a result of a certification process in relation to the recipient which allows his entitlement to be verified before any relief is granted. Under this approach the supervision and control of the operation of the treaty mechanism is with the tax authorities.

The other approach is to delegate to the payer the responsibility for applying or withholding treaty benefits. Thus if the recipient claims to the payer that he is entitled to treaty benefits because he has an address in the treaty partner country concerned then it is up to the payer whether he accepts or rejects this claim. Of course if he is negligent in accepting a claim it is possible he will be subject to penalties, etc if this is discovered by the tax authorities in his own country. However, such discovery is likely to result more from a spot check rather than a systematic review of information made available to the tax authorities. Under this approach the supervision and control rests with the payer, or with the tax advisors to the payer, whom he may call upon for their interpretation of the application of particular provisions.

An outstanding example of the first approach is Switzerland, which incidentally may claim to have one of the older limitation on benefits provisions in a treaty. The dividend article in the Swiss/Netherlands Treaty (Article 9(2)(a)(1)) gives a complete refund of tax withheld if the recipient of the dividend is an enterprise whose capital wholly or partly consists of shares and which owns at least 25 per cent of the capital of the company paying the dividends, provided the relation between the two entities has not been constituted or maintained principally for purposes of assuring receipt of the total refund. This is the wording which appears in the convention of 12 November 1951 as amended by the supplementary convention of 22 June 1966.

The alternative approach is exemplified by the US. It is interesting that, rather than giving attention to the basic policing of treaty entitlement under existing provisions, new and ever more sophisticated qualifications are introduced by the US into its treaties. Some move towards the first approach has, however, has made in the US/Netherlands Treaty with its provisions allowing a person who is not entitled to the benefits of the convention because of the provisions of Article 26(1)(2)(6) to apply to the source state for a determination that it may nevertheless be granted the benefits of the convention. Policing of the basic entitlement (where the source is in the US) remains with the payer, policing of the over-ride is with the tax authorities. 